\title{
Occurrence of jumbo flying squid Dosidicus gigas aggregations associated with the countercurrent ridge off the Costa Rica Dome during 1997 El Niño and 1999 La Niña
}

\author{
Taro Ichii $^{1, *}$, Kedarnath Mahapatra ${ }^{2}$, Tomowo Watanabe ${ }^{3}$, Akihiko Yatsu ${ }^{4}$, \\ Denzo Inagake ${ }^{1}$, Yoshihiro Okada ${ }^{5}$ \\ ${ }^{1}$ National Research Institute of Far Seas Fisheries, 5-7-1 Orido, Shimizu 424-8633, Japan \\ ${ }^{2}$ Earth Weather Inc., 3-16-1, Shinyokohama, Kohoku-ku, Yokohama 222-0033, Japan \\ ${ }^{3}$ Tohoku National Fisheries Research Institute, 3-27-5 Niihama, Shiogama 985-0001, Japan \\ ${ }^{4}$ National Research Institute of Fisheries Science, 12-4 Fukuura 2-chome, Yokohama 236-8648, Japan \\ ${ }^{5}$ Faculty of Marine Science and Technology, Tokai University, 20-1, Orido, Shimizu 424-8610, Japan
}

\begin{abstract}
Factors responsible for aggregations of jumbo flying squid Dosidicus gigas, an important component of the marine food web and target of commercial fisheries off the Costa Rica Dome in the Eastern Tropical Pacific Ocean (ETP), were examined during 2 years of different extreme oceanographic conditions: fall 1997 El Niño and fall 1999 La Niña. A high abundance of squid occurred in association with the well-developed countercurrent ridge (upwelling) off the Costa Rica Dome during fall 1997, but not during fall 1999, when the countercurrent ridge was less developed. Two features of the well-developed countercurrent ridge were considered important for the occurrence of high jumbo flying squid concentrations. Firstly, subsurface chlorophyll a (chl a) maxima were formed along the countercurrent ridge, resulting in integrated chl a concentrations in the upper $100 \mathrm{~m}$ being relatively high considering the generally low productivity of the ETP during an El Niño event. Secondly, a strong salinity front formed along the North Equatorial Countercurrent, which is possibly responsible for retention of jumbo flying squid in the ridge. Large yellowfin tuna Thunnus albacares, which mainly feed on micronekton (small fishes, cephalopods and swimming crabs), as do jumbo flying squid, were also more highly concentrated along the countercurrent ridge during 1997 than during 1999. It was noted that skipjack tuna Katsuwonus pelamis and small yellowfin tuna, which mainly feed on zooplankton, were associated with the equatorial ridge in the ETP, indicating that prey faunal components may also play an important part in the close association of jumbo flying squid with the countercurrent ridge.
\end{abstract}

KEY WORDS: Jumbo flying squid · Dosidicus gigas $\cdot$ El Niño $\cdot$ La Niña $\cdot$ Countercurrent ridge · Equatorial ridge $\cdot$ Yellowfin tuna $\cdot$ Skipjack tuna

Resale or republication not permitted without written consent of the publisher

\section{INTRODUCTION}

\section{Fisheries oceanography}

The Eastern Tropical Pacific Ocean (ETP) is a region of comparatively high productivity, supporting large tuna fisheries and posing interesting oceanographic

*E-mail: ichii@fra.affrc.go.jp questions (Wyrtki 1966). Two major oceanic upwelling zones (ridges) exist in the ETP, the countercurrent and equatorial ridges, which are clearly areas of enhanced biological production (Au \& Perryman 1985, Brandhorst 1985, Fiedler \& Philbrick 1991). Jumbo flying squid Dosidicus gigas, an oceanic-neritic species, are endemic to the eastern Pacific (Nesis 1983, Koronkiewicz 1988). This species forms an important component of the marine food web (Perin et al. 1973), 
and are the target of commercial fisheries off the Costa Rica Dome in the ETP.

The ETP is also a region of significant interannual variability associated with the El Niño Southern Oscillation (ENSO). The effects of El Niño/La Niña events have been frequently discussed in both the scientific literature and news media. Shifts in distribution and changes in abundance of marine animals due to these events receive much attention. It is still unknown, however, how El Niño/La Niña events affect the distribution of jumbo flying squid and even those of abundant tunas, such as yellowfin Thunnus albacares and skipjack Katsuwonus pelamis, in the ETP.

Japanese commercial vessels intermittently harvest jumbo flying squid by jigging off the Costa Rica Dome. Good catches were obtained in this area during fall 1997 El Niño, but poor ones during fall 1999 La Niña. To identify factors influencing aggregations of this species, we studied their distribution using the fishery and survey data obtained during that $2 \mathrm{yr}$ period. Satellitederived sea-surface temperature (SST) and chlorophyll a ( $\mathrm{chl} a$ ) images were analyzed to elucidate environmental changes in the study area during the time of study. Distributions of jumbo flying squid were compared with those of other abundant apex predators (i.e. yellowfin and skipjack tuna) using tuna fishery data.

\section{Physical oceanography}

The physical oceanography of the ETP has been described in detail elsewhere (Wyrtki 1966, Fiedler et al. 1992) and is reviewed briefly here, based mainly on Fiedler et al. (1992). The general features of the surface current system can be deduced from the average thermocline topography (Fig. 1). The $20^{\circ} \mathrm{C}$ isotherm is found in the middle of the thermocline, and its depth is used to represent thermocline depth in the tropical Pacific (Donguy \& Meyers 1987). Thermocline topography has 2 distinct zonal ridges (along ca. 0 and $10^{\circ} \mathrm{N}$ ) and 1 trough (along ca. $\left.5^{\circ} \mathrm{N}\right)$. Sverdrup et al. (1942) presented evidence of surface divergence and upwelling along the 2 ridges.

According to simple geostrophic theory, spatial variations in the depth of the thermocline reflect directional tendencies of the zonal surface currents of the ETP. In the northern hemisphere, the thermocline will be deeper to the right of a current as the observer looks downstream, while in the southern hemisphere the opposite is true. Thus, the broadest current in the ETP, the South Equatorial Current (SEC), flows westward through the region in the same direction as the overlying trade wind, extending from the south-eastern edge of the ETP across the equator to almost $5^{\circ} \mathrm{N}$. North of the thermocline ridge along ca. $10^{\circ} \mathrm{N}$, where the thermocline slopes downward to the north, the North Equatorial Current (NEC) also flows westward with the overlying trade wind. Along the eastern boundary, the thermocline slopes upward toward the coasts of Peru and Baja California, reflecting the equatorward flow of the Peru and California Currents. These coastal systems feed into the eastern 'upstream' ends of the NEC and SEC.

The North Equatorial Countercurrent (NECC) flows eastward between the NEC and SEC, where the trade winds slacken in the doldrums zone associated with the Intertropical Convergence Zone. The NECC shows considerable seasonal variation. It is strong and well developed from August through December, when the slope of the thermocline ridge is steep (Wyrtki 1966). On approaching the ocean's eastern boundary, a large part of the flow of NECC veers to the north in a counterclockwise direction to merge with the NEC around a feature in the ocean density structure called the

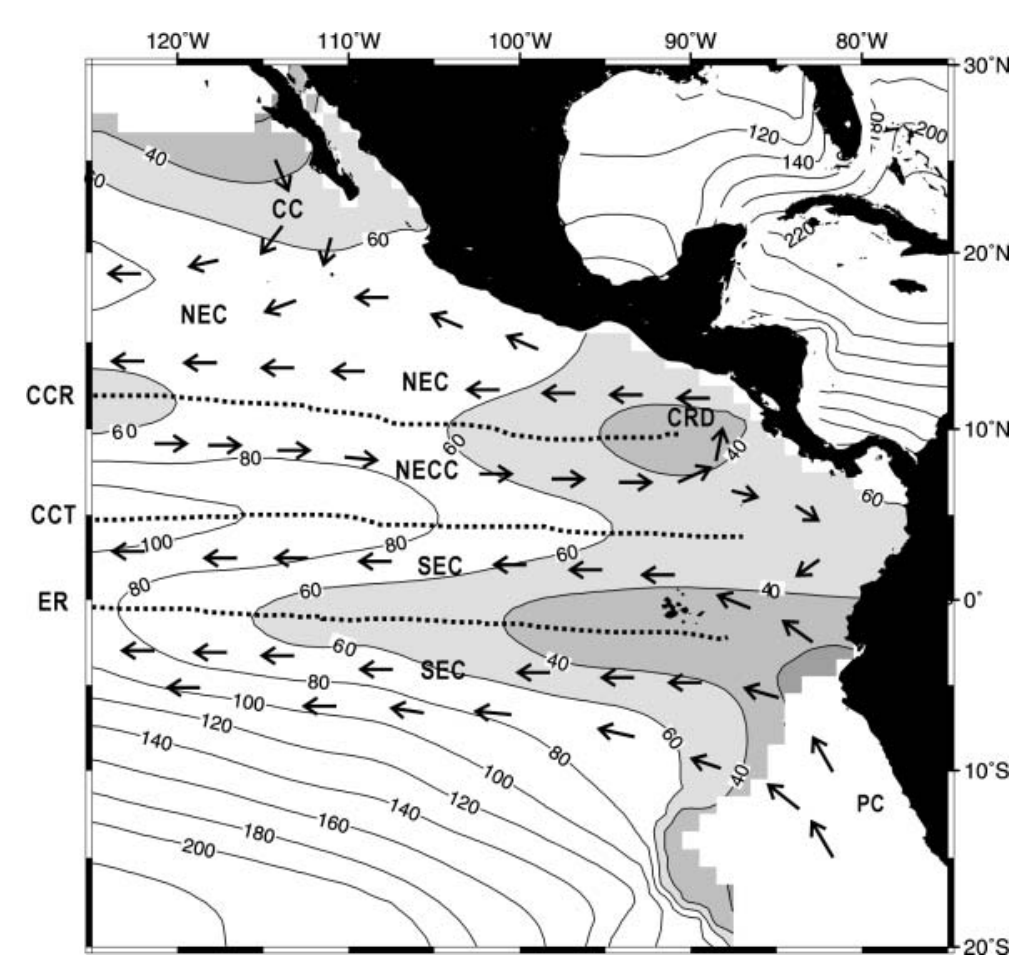

Fig. 1. General patterns in thermocline $\left(20^{\circ} \mathrm{C}\right.$ isotherm) depths $(\mathrm{m})$ and surface currents, July-December. NEC: North Equatorial Current; NECC: North Equatorial Countercurrent; SEC: South Equatorial Current; CC: California Current; PC: Peru Current; CCR: Countercurrent Ridge; CCT: Countercurrent Trough; ER: Equatorial Ridge; CRD: Costa Rica Dome. Thermocline data from Levitus \& Boyer (1994); surface currents from Wyrtki (1966) 
Costa Rica Dome. This dome is a permanent feature, relatively consistently located near latitude $9^{\circ} \mathrm{N}$ and longitude $89^{\circ} \mathrm{W}$. The other part of the NECC flow veers to the south, or clockwise, to merge into the SEC.

\section{MATERIALS AND METHODS}

Fishery data. Japanese commercial jigging vessels operating in this area have a capacity of 299 to 498 tonnes, and are equipped with around 100 automatic jigging machines with double reels. To determine the distribution and relative abundance of jumbo flying squid Dosidicus gigas in the fishing ground during 1997 and 1999, catch (tonnes vessel ${ }^{-1} \mathrm{~d}^{-1}$ ) derived from fishery jigging data was calculated for each $1^{\circ}$ latitude $\times 1^{\circ}$ longitude for each month. Catch data for yellowfin Thunnus albacares and skipjack Katsuwonus pelamis tuna, the 2 most abundant tuna species in the ETP, were provided by the Inter-American Tropical Tuna Commission (IATTC). Tunas are caught by purse seiners in 3 types of schools: those in which the fish are associated with dolphins, those in which the fish are associated with floating objects such as flotsam or fishaggregating devices, and those in which the fish are associated only with other fishes. Yellowfin tuna are primarily caught in dolphin-associated schools while skipjack tuna are primarily caught in floating objectassociated schools (IATTC 1999). In the case of yellowfin tuna, body size compositions of fish caught differ significantly among the different types of schools; small yellowfin (40 to $60 \mathrm{~cm}$ fork length) are dominant in floating object-associated schools whereas large fish (60 to $140 \mathrm{~cm}$ ) are dominant in dolphin-associated schools, with middle-sized fish occurring in freeswimming schools (IATTC 1989). Therefore, for skipjack tuna, the catches from all types of schools were combined for the analyses, whereas yellowfin tuna in floating object-associated schools and in dolphinassociated schools were chosen and calculated separately for each $1^{\circ}$ latitude $\times 1^{\circ}$ longitude during the 3rd and 4th quarters (i.e. July to December) of 1997 and 1999.

Satellite image analyses. SST images from the Advanced Very High Resolution Radiometer (AVHRR) and chl a concentration images from the Sea-viewing Wide Field-of-view Sensor (SeaWiFS) carried by the National Oceanic and Atmospheric Administration (NOAA) polar-orbiting satellites and OrbView-2 (formerly SeaStar) satellite respectively, were used. The satellite images were used to derive monthly mean distributions of SST and near-surface chl a concentrations during the month of October in both 1997 and 1999.

SST images were obtained from the version 4.1 Pathfinder global data sets produced by the National
Aeronautics and Space Administration (NASA) Physical Oceanography Distributed Active Archive Center (PODAAC) at the Jet Propulsion Laboratory (JPL), California Institute of Technology (Vazquez et al. 1998).

The SeaWiFS-derived chl a images were obtained from Goddard DAAC as Level 2 GAC products processed using the 3rd SeaWiFS reprocessing programs (McClain 2000). In total, 45 multiple orbit Level 2 GAC data for October 1997 and 71 for October 1999 were used for spatial and temporal binning to produce monthly mean chl a images (Campbell et al. 1995). The images were then co-registered with SST images using identical resolution $(9 \mathrm{~km})$ and map projection. The range of satellite inferred chl a concentrations were close to the range of ship observed values. Hence a linear color bar depicting the range of chl a concentrations between 0.001 and $1.5 \mathrm{mg} \mathrm{m}^{-3}$ is presented at the bottom of the images (see Fig. 5).

Shipboard survey. RV 'Kaiyo Maru' and RV 'Shoyo Maru' conducted oceanographic surveys from 4 to 10 October 1997 and from 29 September to 31 October 1999 respectively. CTD casts were made at 12 stations in 1997 and 22 in 1999 (Fig. 2). XBTs were deployed at 3 and 23 stations in 1997 and 1999 respectively, and XCTDs at 10 stations in 1999 only. Water temperature data during early October 1997, from the Tropical Atmosphere Ocean (TAO) array of 5 moored buoys (McPhaden 1999), were also used for the area south of $2^{\circ} 30^{\prime} \mathrm{N}$, where no shipboard observations were conducted during the cruise in 1997. Chl a concentrations were measured at 12 grid sampled CTD stations during both 1997 and 1999 cruises. For chl a analyses, aliquots of 500 or $1000 \mathrm{ml}$ obtained from 11 depth levels $(0,10,20,30,40,50,60,70,80,90,100 \mathrm{~m})$ were filtered through Whatman GF/F filters, which were extracted with $90 \%$ acetone, and the fluorescence was measured (Parsons et al. 1984a). Chl a data for 1997 are from Shiomoto (1999).

Adult squid were collected with several handlines for up to $3 \mathrm{~h}$ at 6 stations from 5 to 10 October 1997 and from 1 to 7 October 1999. Each line was equipped with several plastic jigs of various sizes and colors (Daiwa Gyogu). All squid caught were identified to species, sexed, and mantle lengths measured to the nearest $1 \mathrm{~cm}$ (see Fig. 10 for locations of jigging stations).

Artificial fertilization. Artificial fertilization was carried out in temperatures of 24 and $28^{\circ} \mathrm{C}$ to examine the influence of warm surface water temperatures during El Niño events on the hatching rate of Dosidicus gigas. A mature mated female (37 cm mantle length), caught by RV 'Shoyo Maru', was obtained from $08^{\circ} 00^{\prime} \mathrm{N}$, $94^{\circ} 41^{\prime} \mathrm{W}$ in October 1999. The procedures for artificial fertilization followed those of Sakurai et al. (1995) and Yatsu et al. (1999a). For this experiment, $0.2 \mu \mathrm{m}$ filtered seawater was prepared in order to avoid bac- 
terial infection. Ripe eggs were obtained from the oviducts and sperm masses were obtained from the seminal receptacles on the buccal membrances. During the fertilization procedure, jelly-water, prepared by adding filtered seawater to lyophilized oviducal gland powder processed from Ommastrephes bartramii, was added to the eggs in order to stimulate chorion expansion. Two groups of ca. 700 fertilized eggs held in petri dishes, each dish containing ca. 50 eggs with filtered seawater, were kept in the dark at 24 and $28^{\circ} \mathrm{C}$, respectively. Filtered seawater in the petri dishes was changed daily. The renewal water was stabilized at either 24 or $28^{\circ} \mathrm{C}$ before each daily water change.

\section{RESULTS}

\section{Distribution and abundance of the jumbo flying squid}

The 1997 fishery operation for Dosidicus gigas was conducted from June through November (Fig. 3). Fishing grounds were formed in more or less the same area along 7 to $9^{\circ} \mathrm{N}$ between 92 and $100^{\circ} \mathrm{W}$ throughout the fishing season. The average CPUE (catch per unit effort; tonnes per vessel per day) was high, with 19.4 tonnes in August, 15.2 tonnes in September and 8.5 tonnes in October. Because of the good catch rate, as many as 37 Japanese fishing boats operated in the fishing ground. In 1999, the fishery was conducted from August through September (Fig. 4). Even though fishing activities were undertaken in the same areas as in 1997, the average CPUE was very low, with 3.1 tonnes in August and 2.3 tonnes in September. Only 7 fishing vessels operated during this season due to the poor catch rates. In both years, jumbo flying squid abundances within the 200 nautical mile (n mile) economic zone are unknown, because the fishery was permitted only on the high seas.

\section{Satellite observations}

In October 1997, SST was warmer throughout the ETP, with 26 to $30^{\circ} \mathrm{C}$ north of the equator (Fig. 5). Advection of cold water $\left(<21^{\circ}\right)$ from the Peru Current was limited to the coastal waters off Peru. In October 1999, however, SST was cooler in the ETP, with 22 to $26^{\circ} \mathrm{C}$ north of the equator. Cool water (ca. $22^{\circ} \mathrm{C}$ ) upwelled off the Gulf of Tehuantepec (ca. $12^{\circ} \mathrm{N}, 95^{\circ} \mathrm{W}$ ) and cold water from the Peru Current prevailed south of the equator.

In October 1997, SeaWiFS surface chl a concentrations were low compared with 1999 throughout the ETP, even in equatorial and coastal waters, except off Peru (Fig. 5). High chl a concentrations (> ca. $1.5 \mathrm{mg} \mathrm{m}^{-3}$ ) occurred only in a limited oceanic area (ca. $15^{\circ} \mathrm{N}, 103^{\circ} \mathrm{W}$ ) and in coastal waters off Peru. Slightly higher chl a concentrations (ca. $0.3 \mathrm{mg} \mathrm{m}^{-3}$ ) were observed around the countercurrent ridge $\left(7^{\circ} \mathrm{N}, 94^{\circ} \mathrm{W}\right.$ to $\left.12^{\circ} \mathrm{N}, 100^{\circ} \mathrm{W}\right)$. In October 1999, SeaWiFS surface chl a concentrations were higher over wide areas in the ETP, especially in coastal waters such as the Gulf of Tehuantepec and off Peru (> ca. $1.5 \mathrm{mg} \mathrm{m}^{-3}$ ). Moderately high concentrations
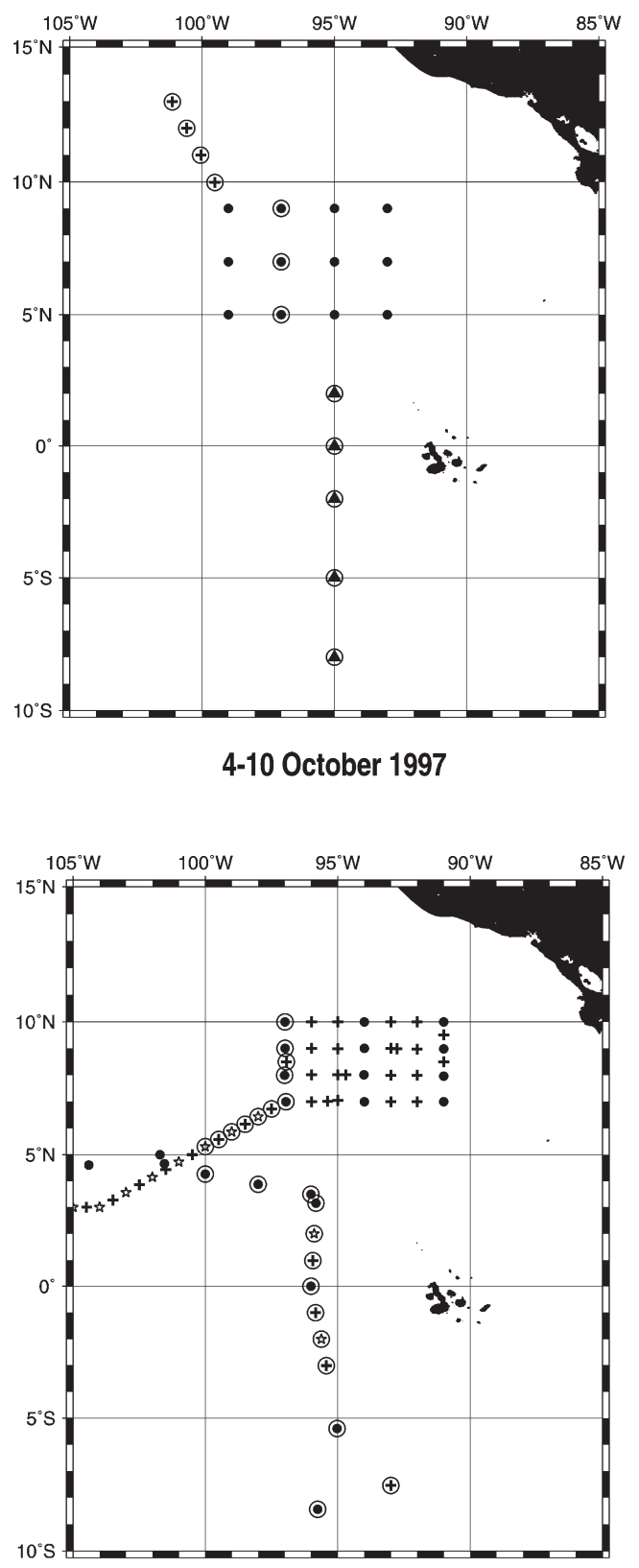

29 September - 31 October 1999

Fig. 2. Oceanographic observation stations. $\bullet$ : CTD; is: XCTD; +: XBT; $\Delta$ : TAO (moored buoys' data). O: data used for describing north-south cross-sections of temperatures in Fig. 7 
(ca. 0.4 to $0.5 \mathrm{mg} \mathrm{m}^{-3}$ ) were observed all along the equatorial and countercurrent ridges.

\section{Shipboard oceanographic observations}

Oceanographic environments in October are shown together with the distribution of CPUEs of jumbo flying squid from mid-September to mid-October for both years (Fig. 6). In October 1997, the thermocline topography at 7 to $11^{\circ} \mathrm{N}$ and 95 to $102^{\circ} \mathrm{W}$ showed a distinct subsurface upwelling, with which high CPUE coincided. The subsurface upwelling at this site also corresponded to the countercurrent thermocline ridgetrough system off the Costa Rica Dome. The thermo- cline ridge near $9^{\circ} \mathrm{N}$ and trough near $5^{\circ} \mathrm{N}$ indicated the northern and southern flanks of the North Equatorial Countercurrent (NECC) respectively. The northsouth cross section of water temperature in 1997 indicates a well-developed subsurface upwelling at the countercurrent ridge but considerably depressed upwelling at the equator (Fig. 7). A huge accumulation of warm $\left(\geq 25^{\circ} \mathrm{C}\right)$ surface water and resulting thermocline depression are evident in the equatorial surface water masses. The thermocline at the equator was spreading because of the Equatorial Undercurrent (EUC). In addition, the horizontal distribution of salinity at $10 \mathrm{~m}$ depth showed a strong front along the NECC (Fig. 6).

Integrated chl a concentrations in the upper $100 \mathrm{~m}$ depth for October 1997 were relatively high ( $\geq 25 \mathrm{mg}$
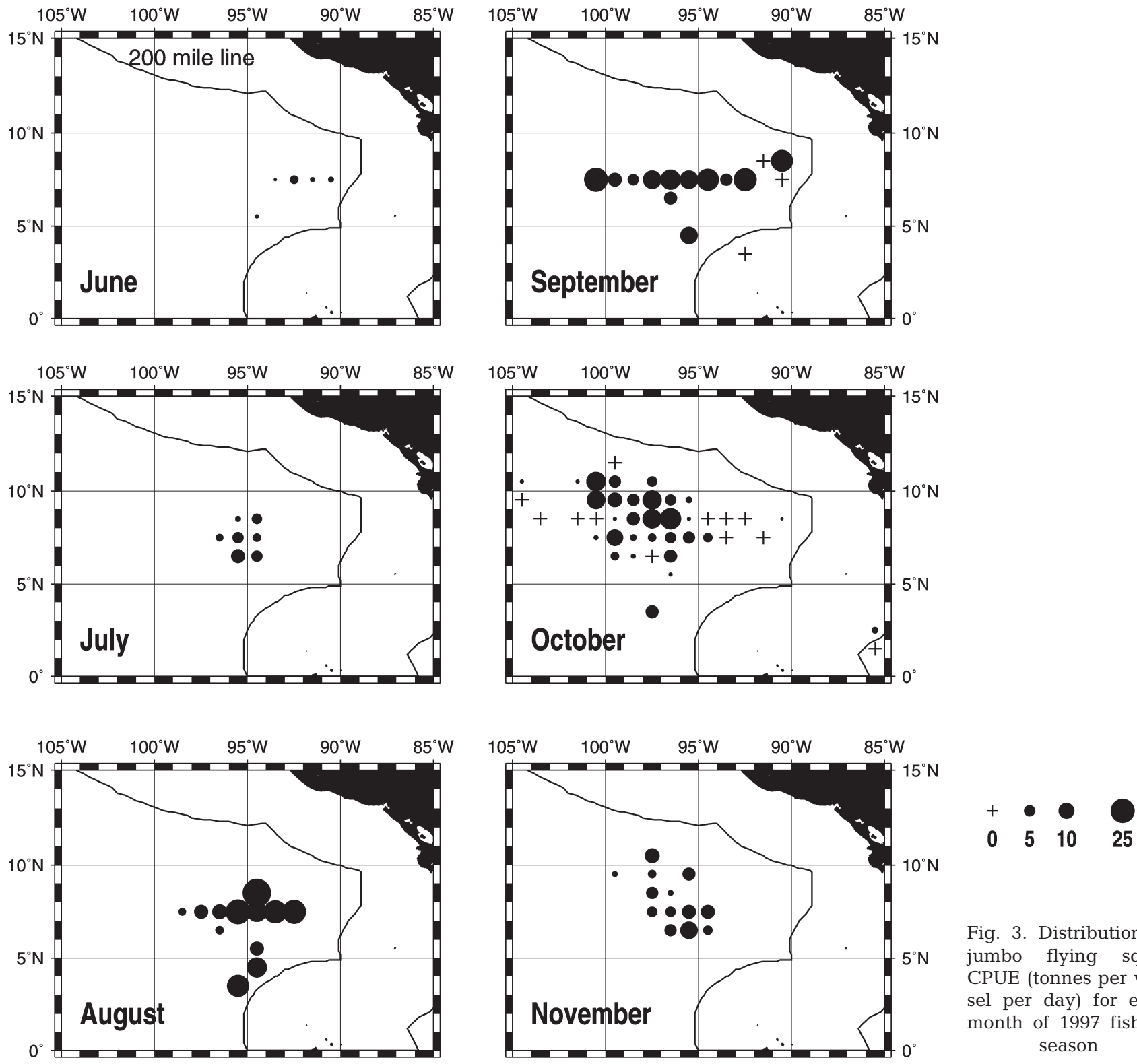

Fig. 3. Distribution of jumbo flying squid CPUE (tonnes per vessel per day) for each month of 1997 fishing season 

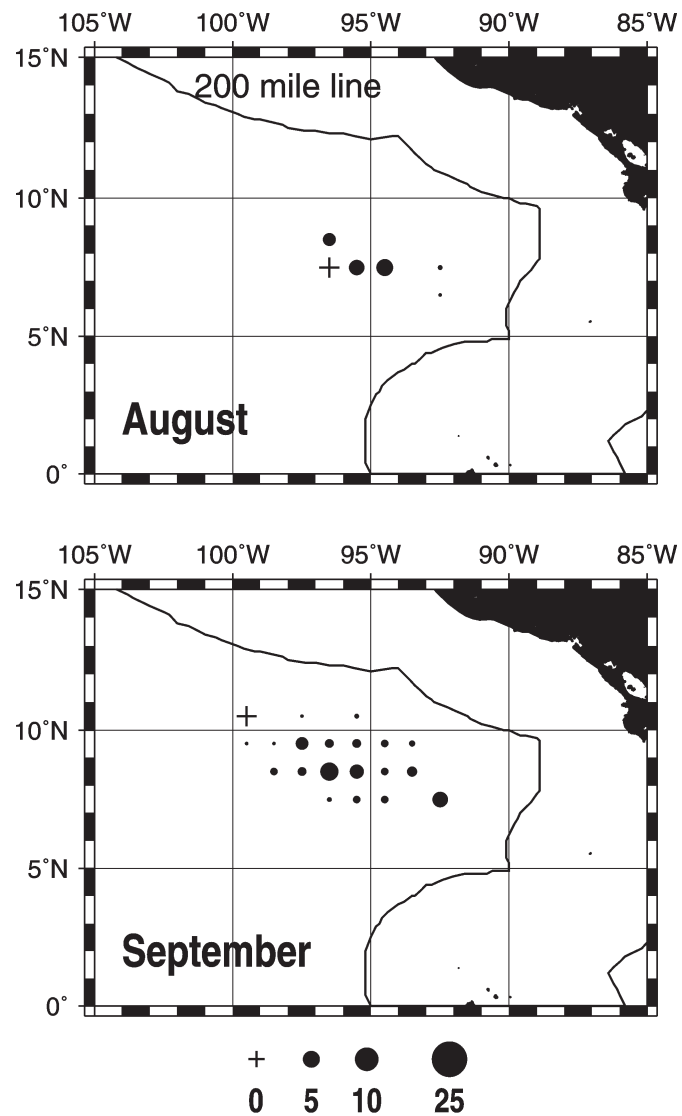

Fig. 4. Distribution of jumbo flying squid CPUE (tonnes per vessel per day) for each month of 1999 fishing season

$\mathrm{m}^{-2}$ ) around the subsurface upwelling area (Fig. 6). The relatively high chl $a$ area also appeared to be associated with the lower surface salinity $(\leq 33.3)$ area. The north-south cross sections of chl $a$ indicate subsurface chl a maxima $\left(0.4 \mathrm{mg} \mathrm{m}^{-3}\right)$ at ca. $50 \mathrm{~m}$ depth, which more or less coincided with the halocline (Fig. 8).

In October 1999, the slope between the countercurrent thermocline ridge $\left(10^{\circ} \mathrm{N}\right)$ and trough $\left(5^{\circ} \mathrm{N}\right)$ was reduced as the trough was $30 \mathrm{~m}$ shallower than in 1997 (Fig. 6). CPUEs were low along the countercurrent ridge. The north-south cross section of water temperature indicates well-developed subsurface upwelling at the equator but relatively flattened themocline topography at the countercurrent ridge-trough system (Fig. 7). The EUC shown by the thermocline spread at the equator was clearly apparent at a shallower depth than in 1997 because of a smaller accumulation of warm surface water. The cold surface water $\left(\leq 21^{\circ} \mathrm{C}\right)$ south of the equator is from the Peru Current. The salinity front along the NECC was weaker than in 1997 (Fig. 6).

Integrated chl a concentrations for October 1999 showed a tendency to be higher toward the coast. The high chl a $\left(\geq 25 \mathrm{mg} \mathrm{m}^{-2}\right)$ areas were restricted to lower salinity $(\leq 33.3)$ areas of the countercurrent ridge (Fig. 6). The north-south cross sections of chl a indicate surface chl a maxima $\left(0.6 \mathrm{mg} \mathrm{m}^{-3}\right)$ in the upper halocline (20 to $30 \mathrm{~m}$ depth) (Fig. 9).

\section{Size and maturity of jumbo squid collected by the jigging survey}

A total of 88 Dosidicus gigas and 24 purpleback flying squid Sthenoteuthis oualaniensis were collected during October 1997, and 199 D. gigas and 15 S. oualaniensis during October 1999. In both years, positive catches of $D$. gigas were generally confined to shallower themocline areas, with no $D$. gigas occurring in the southwestern part of the survey area, i.e. deeper thermocline areas (Fig. 10). S. oualaniensis were captured from the southwestern or more pelagic area, in contrast to the distribution of $D$. gigas.

In October 1997, mantle lengths of jumbo squid ranged between 16 and $35 \mathrm{~cm}$ (mostly between 17 and $28 \mathrm{~cm})$. Females were dominant, comprising $83(94 \%)$ of 88 individuals, with 4 females $(5 \%)$ having copulated (Fig. 11). In October 1999, mantle lengths ranged between 15 and $39 \mathrm{~cm}$ (mostly between 18 and $29 \mathrm{~cm}$ ). Females were represented by 180 (90\%) of 199 individuals, with 27 females (15\%) having copulated. Both years showed similar length compositions and sex ratio (Fig. 11). There was also a tendency that mature and larger females were more frequently distributed toward southern areas in both years (Fig. 12).

\section{Artificial fertilization}

Hatching of Dosidicus gigas occurred $4 \mathrm{~d}$ after fertilization at $24^{\circ} \mathrm{C}$, and $3 \mathrm{~d}$ after fertilization at $28^{\circ} \mathrm{C}$. Hatching rates were identical (16\%) at both temperatures (Table 1). Paralarvae had well-developed ink sacs, fins and extensive probosces on the day of hatching. Because they were kept in filtered water (i.e. without food), they became weaker as their yolks were exhausted. Days for which $50 \%$ of paralarvae survived numbered 3 at $24^{\circ} \mathrm{C}$ and 2 at $28^{\circ} \mathrm{C}$. The maximum survival periods recorded were $10 \mathrm{~d}$ at $24^{\circ} \mathrm{C}$ and $5 \mathrm{~d}$ at $28^{\circ} \mathrm{C}$.

\section{Yellowfin and skipjack tuna catch distribution}

During the latter half (July to December) of 1997, large catches of large yellowfin tuna (i.e. dolphin-associated schools) were made along the countercurrent ridge, including the area west of the Costa Rica Dome (Fig. 13), where jumbo flying squid CPUE was also 
high (Fig. 6). Catches were very limited in coastal waters. During the latter half of 1999, catches of large yellowfin tuna were less concentrated along the countercurrent ridge (i.e. relatively high only between ca. $101^{\circ} \mathrm{W}$ and $105^{\circ} \mathrm{W}$ ) and were very poor between ca. $90^{\circ} \mathrm{W}$ and $100^{\circ} \mathrm{W}$, where jumbo flying squid CPUE was also low. Catches in coastal waters were relatively greater than in 1997.

During the latter half of 1997, catches of skipjack tuna were relatively greater south of the equator (Fig. 13). Higher catches were spread over the area along ca. $1^{\circ} \mathrm{N}$ to $5^{\circ} \mathrm{S}$, corresponding roughly to the equatorial
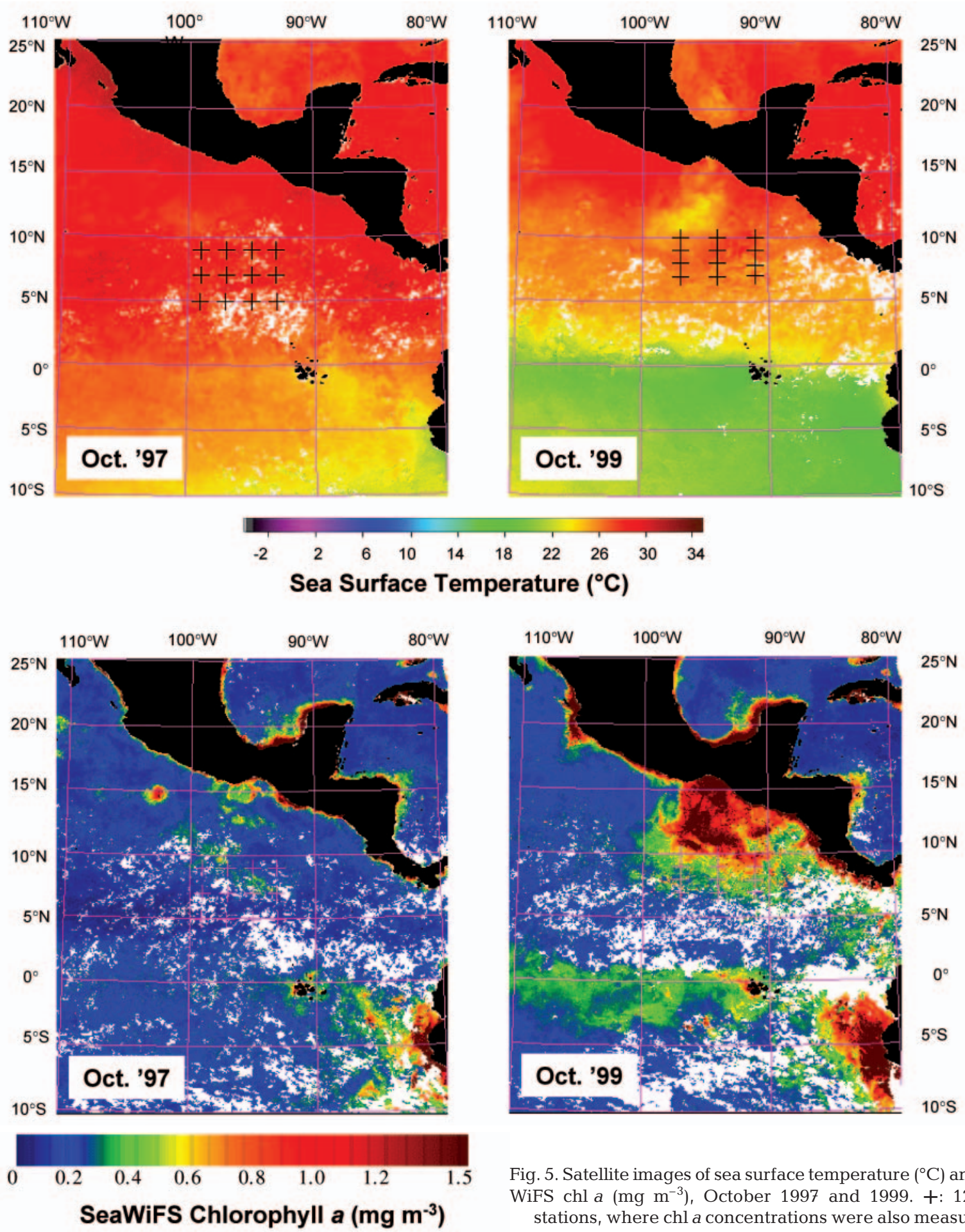

Fig. 5. Satellite images of sea surface temperature $\left({ }^{\circ} \mathrm{C}\right)$ and SeaWiFS chl a $\left(\mathrm{mg} \mathrm{m}^{-3}\right)$, October 1997 and 1999. +: 12 CDT stations, where chl a concentrations were also measured 
(a) Jumbo squid CPUE
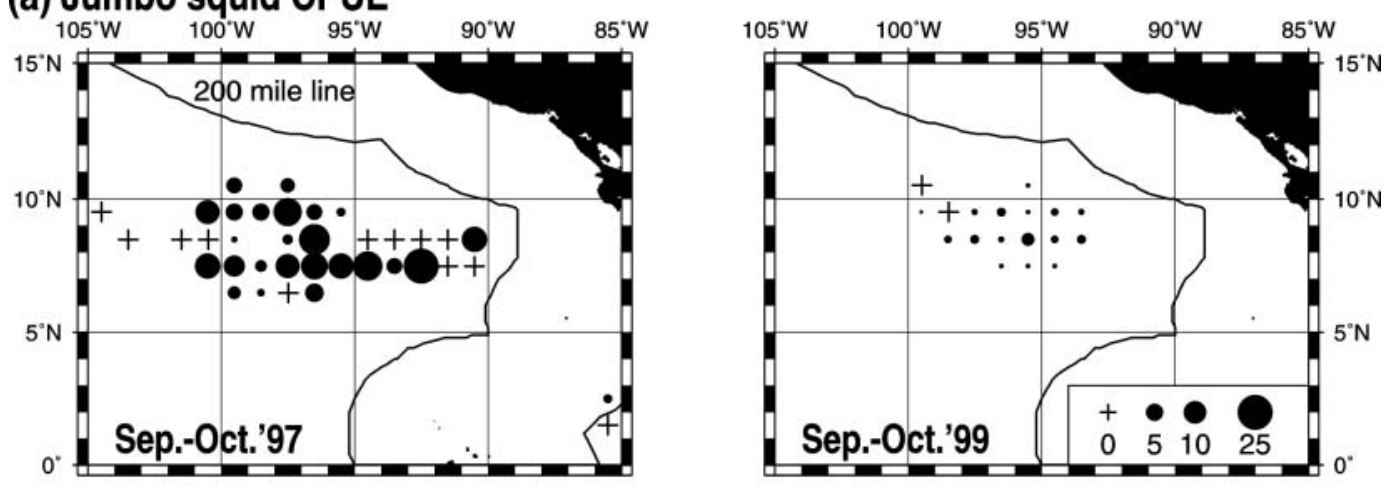

(b) Thermocline depth (m)
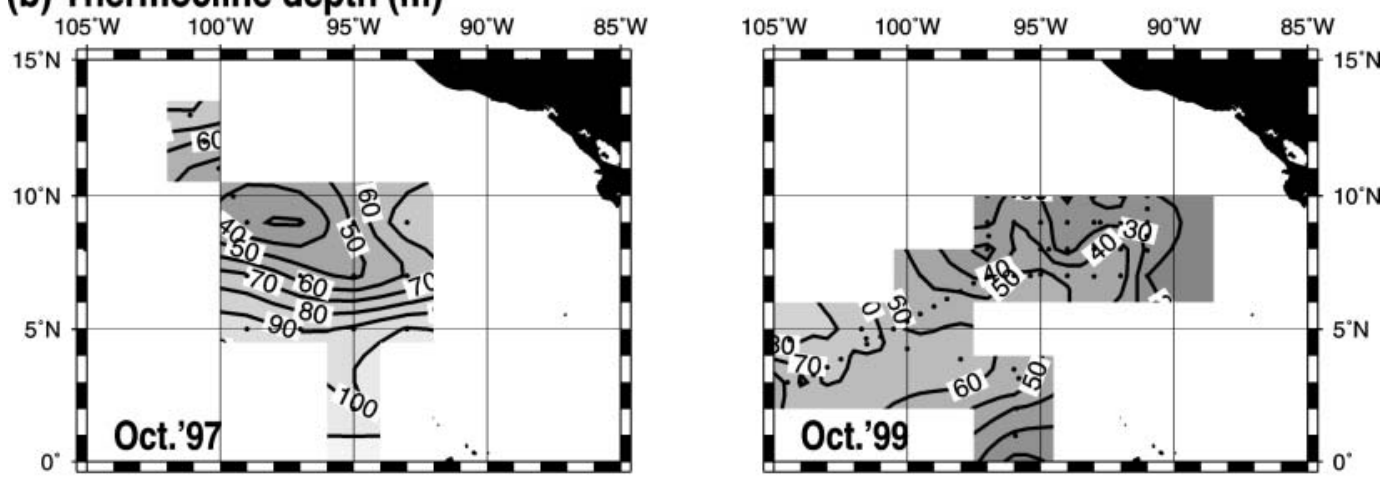

(c) Salinity at $10 \mathrm{~m}$
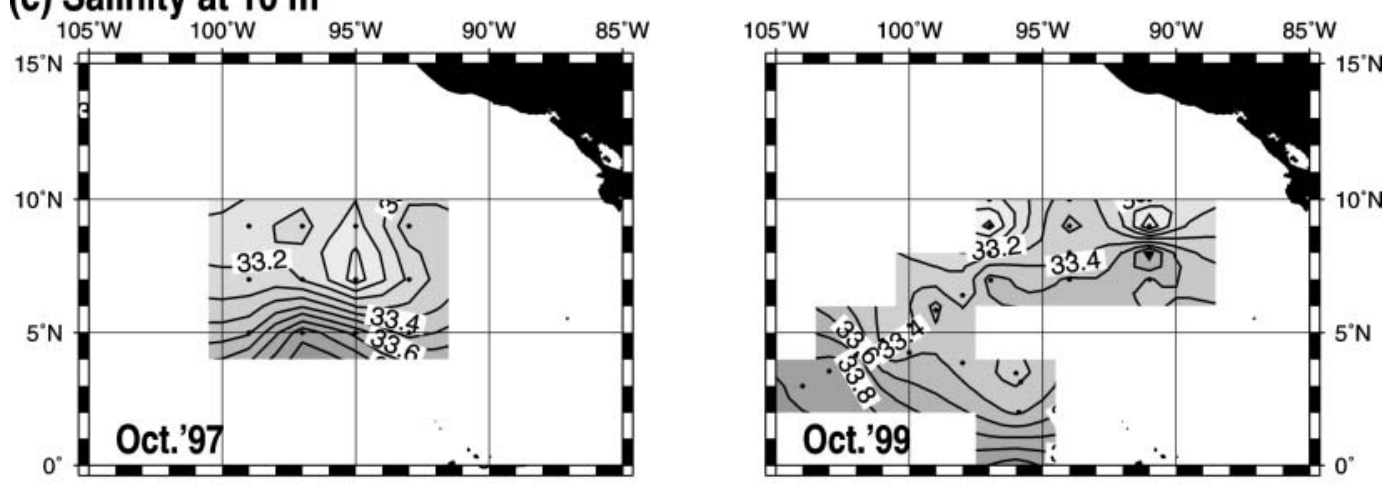

(d) Chlorophyll-a $\left(\mathrm{mg} / \mathrm{m}^{2}\right)$ between 0 and $100 \mathrm{~m}$
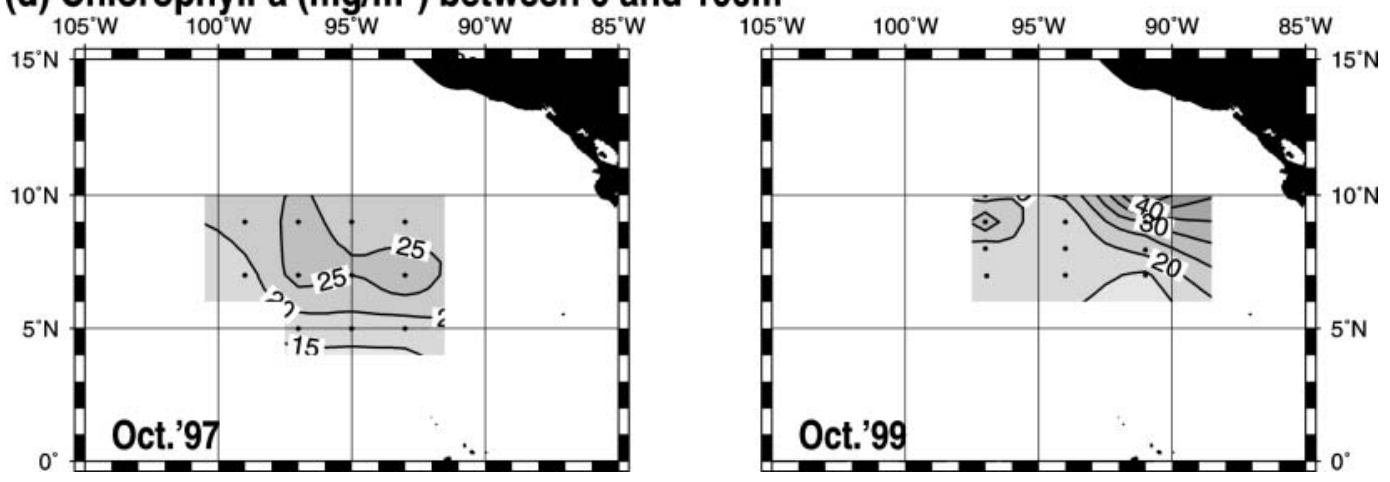

Fig. 6. (a) Jumbo flying squid CPUE (tonnes per vessel per day), mid-September to mid-October, 1997 and 1999; (b) thermocline $\left(20^{\circ} \mathrm{C}\right.$ isotherm) depth; (c) salinity at $10 \mathrm{~m} \mathrm{depth}$; (d) integrated chl a $\left(\mathrm{mg} \mathrm{m}^{-2}\right)$ for upper $100 \mathrm{~m}$, October 1997 and 1999 

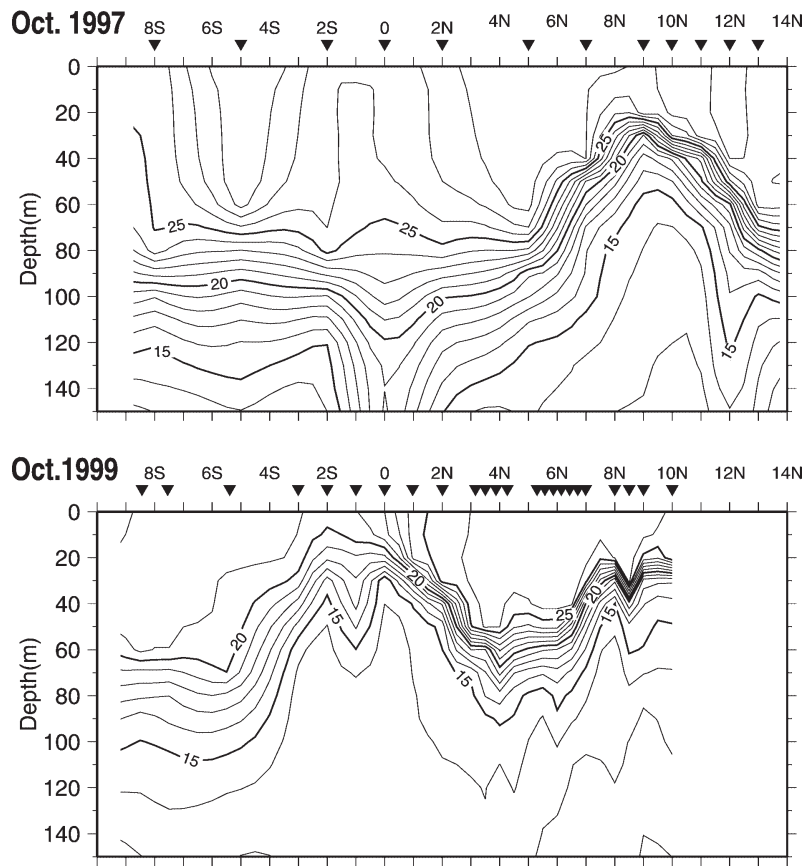

Fig. 7. North-south sections of temperature $\left({ }^{\circ} \mathrm{C}\right)$, October 1997 and 1999. Layout of stations shown in Fig. 2. $\mathbf{v}$ : station locations

upwelling, which was overlain entirely by warm surface water due to the El Niño event (Fig. 7). During the latter half of 1999, skipjack catches were greater north of the equator, being concentrated in the area along 1 to $5^{\circ} \mathrm{N}$, which corresponds to the warmer surface side of the equatorial upwelling (Fig. 7).

The catch distributions of small yellowfin tuna (i.e. floating object-associated schools) were very similar to those of skipjack tuna in both years (Fig. 13).

\section{DISCUSSION}

\section{Oceanographic factors related to aggregations of jumbo flying squid}

We observed typical El Niño/La Niña contrasts in oceanographic structures, i.e. a steeply sloped countercurrent ridge and flattened equatorial ridge during fall 1997 El Niño, compared with a flattened countercurrent ridge and steep equatorial ridge during fall 1999 La Niña (Figs. 6b \& 7). The high abundance of jumbo flying squid during El Niño in October 1997 coincided with the countercurrent ridge (i.e. upwelling) west of the Costa Rica Dome. Association of high abundance of this species with the upwelling was also observed off Costa Rica during the early stage of El Niño during October to December 1986 (Koronkiewicz 1988). Furthermore, an extraordinary abundance of ommastrephid paralarvae was found in a westward extension of the Costa Rica Dome (i.e. the countercurrent ridge) during El Niño during August to November 1987 (Vecchione 1999). Thus, the paralarvae of jumbo flying squid seem to be predominant in this area. Therefore, we suggest that the concentrations of jumbo flying squid tend to occur in association with the well-developed countercurrent ridge during El Niño.

The question arises, therefore, which of the environmental features of the well-developed countercurrent ridge are responsible for the occurrence of jumbo squid aggregations? During El Niño in fall 1997, surface chl a concentrations were lower all over the ETP, even in equatorial and coastal waters. However, integrated chl a concentrations in the upper $100 \mathrm{~m}$ depth were relatively higher $\left(\geq 25 \mathrm{mg} \mathrm{m}^{-2}\right)$ around the countercurrent ridge due to the occurrence of subsurface chl a maxima, the latter being caused by a variety of factors including light intensity, vertical mixing and the availability of surface nutrients (Parsons et al. 1984b, Mann \& Lazier 1991). Chl a maxima are usually located in the nitracline in depths of sufficient light intensity. The nitrate flux is sufficient to support photosynthesis through a few meters of the water column around the nitracline, but is insufficient for maintaining photosynthesis throughout the entire upper layer. In the ETP, seasonal changes in chl a standing stock
Table. 1 Results of artificial fertilization experiments for Dosidicus gigas Sampling position and the mantle length of the female used are also given

\begin{tabular}{|c|c|c|c|c|c|}
\hline \multicolumn{6}{|c|}{ Sampling position } \\
\hline \multicolumn{3}{|c|}{ Latitude (N) } & \multicolumn{3}{|c|}{$08^{\circ} 00^{\prime} \mathrm{N}$} \\
\hline \multicolumn{3}{|c|}{ Longitude (W) } & \multicolumn{3}{|c|}{$94^{\circ} 41^{\prime} \mathrm{W}$} \\
\hline \multicolumn{3}{|c|}{$\operatorname{SST}\left({ }^{\circ} \mathrm{C}\right)$} & \multicolumn{3}{|c|}{26.5} \\
\hline \multicolumn{3}{|c|}{ Mantle length (cm) } & \multicolumn{3}{|c|}{37} \\
\hline \multicolumn{3}{|c|}{ Shipboard rearing } & Expt 1 & \multicolumn{2}{|c|}{ Expt 2} \\
\hline \multirow{2}{*}{\multicolumn{3}{|c|}{$\begin{array}{l}\text { Date of artificial insemination } \\
\text { Temperature of incubator }\left({ }^{\circ} \mathrm{C}\right)\end{array}$}} & \multicolumn{3}{|c|}{4 October 1999} \\
\hline & & & 28 & \multicolumn{2}{|c|}{24} \\
\hline \multicolumn{3}{|c|}{ No. of eggs used (A) } & 695 & \multicolumn{2}{|c|}{631} \\
\hline \multicolumn{3}{|c|}{ No. of hatchlings (B) } & 113 & \multicolumn{2}{|c|}{101} \\
\hline \multicolumn{3}{|c|}{ Hatching rate (B/A) } & $16 \%$ & \multirow{2}{*}{\multicolumn{2}{|c|}{$\begin{array}{c}16 \% \\
8 \text { October } 1999\end{array}$}} \\
\hline \multicolumn{3}{|c|}{ Hatching date } & 7 October 1999 & & \\
\hline \multicolumn{6}{|c|}{ No. of surviving paralarvae } \\
\hline $1 \mathrm{~d}$ old & 67 & 73 & $6 \mathrm{~d}$ old & 0 & 26 \\
\hline $2 \mathrm{~d}$ old & 36 & 61 & $7 \mathrm{~d}$ old & 0 & 20 \\
\hline $3 \mathrm{~d}$ old & 18 & 46 & $8 \mathrm{~d}$ old & 0 & 12 \\
\hline $4 \mathrm{~d}$ old & 5 & 33 & $9 \mathrm{~d}$ old & 0 & 1 \\
\hline $5 \mathrm{~d}$ old & 4 & 29 & $10 \mathrm{~d}$ old & 0 & 1 \\
\hline
\end{tabular}



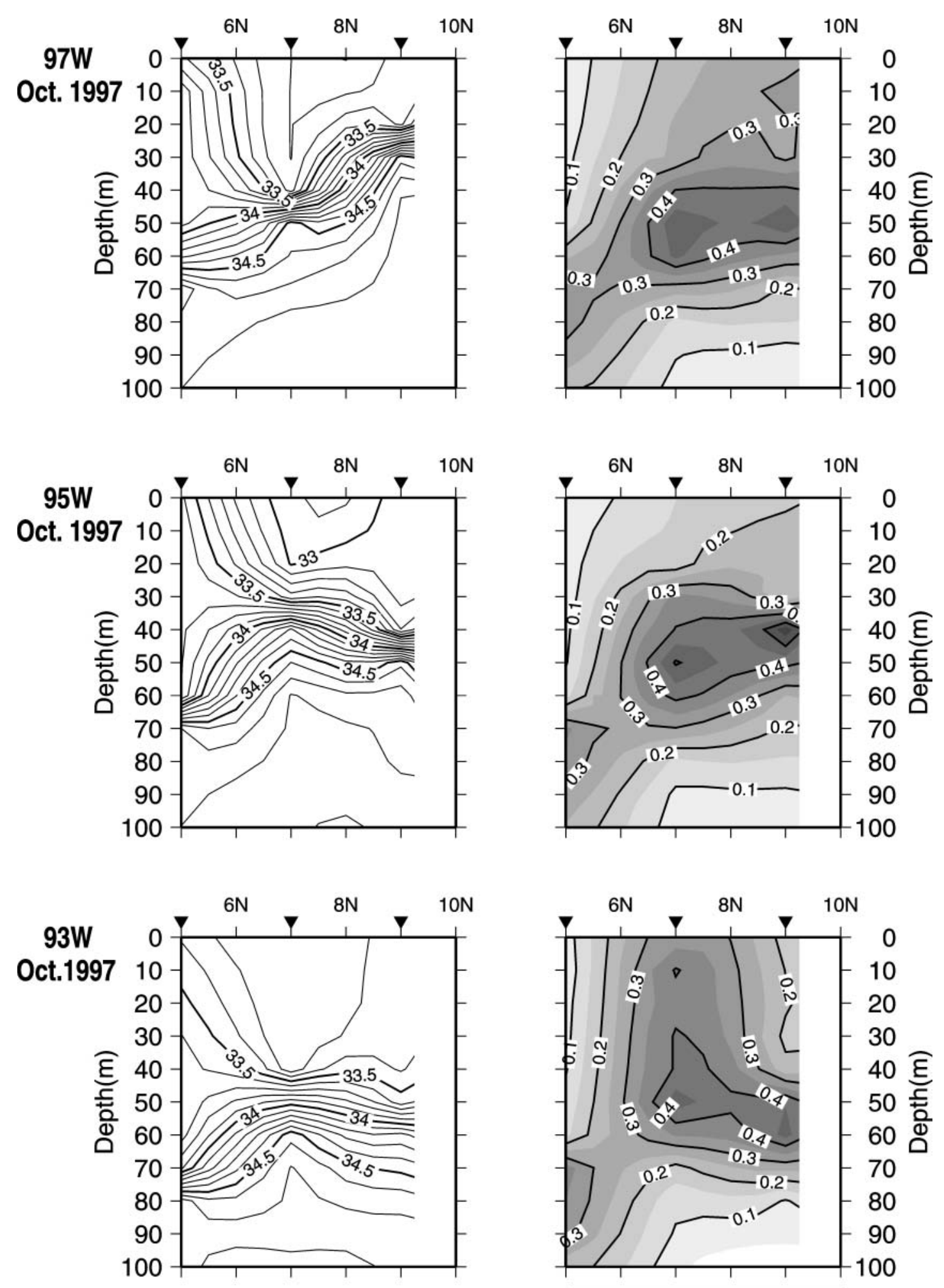

Salinity

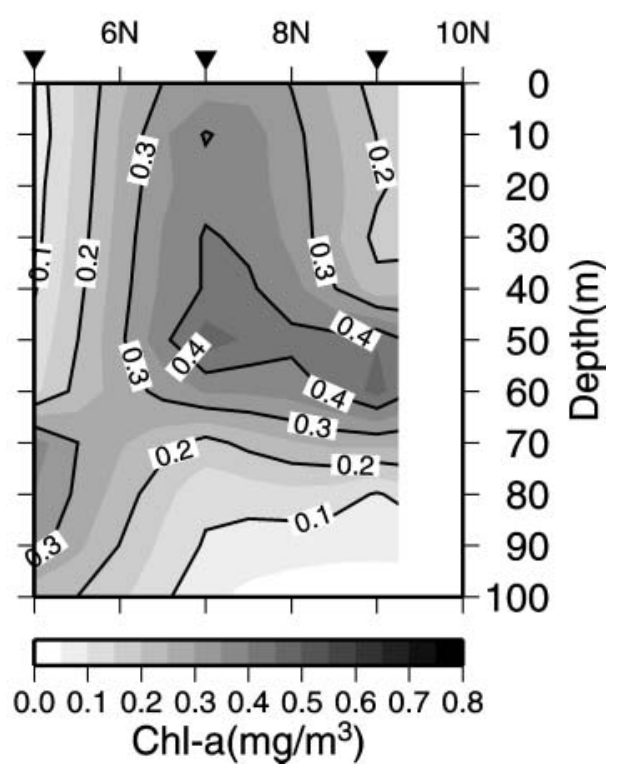

Fig. 8. North-south sections of salinity and chl a $\left(\mathrm{mg} \mathrm{m}^{-3}\right)$ along 3 meridians $\left(97^{\circ} \mathrm{W}, 95^{\circ} \mathrm{W}\right.$ and $\left.93^{\circ} \mathrm{W}\right)$ in the grid survey, October 1997.v: station locations 

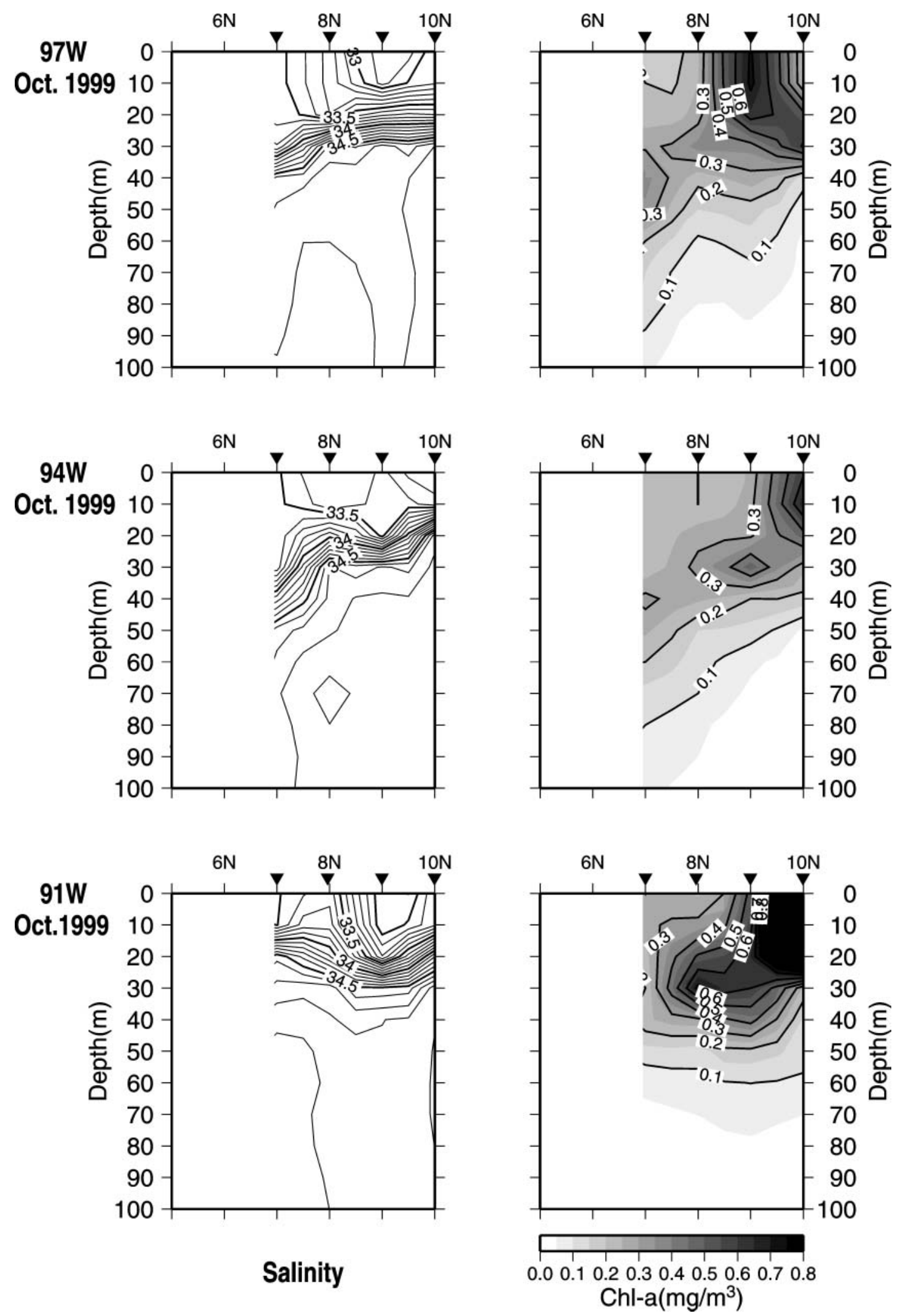

Fig. 9. North-south sections of salinity and chl a $\left(\mathrm{mg} \mathrm{m}^{-3}\right)$ along 3 meridians $\left(97^{\circ} \mathrm{W}, 94^{\circ} \mathrm{W}\right.$ and $\left.91^{\circ} \mathrm{W}\right)$ in the grid survey, October 1999. $\mathbf{v}$ : station locations 

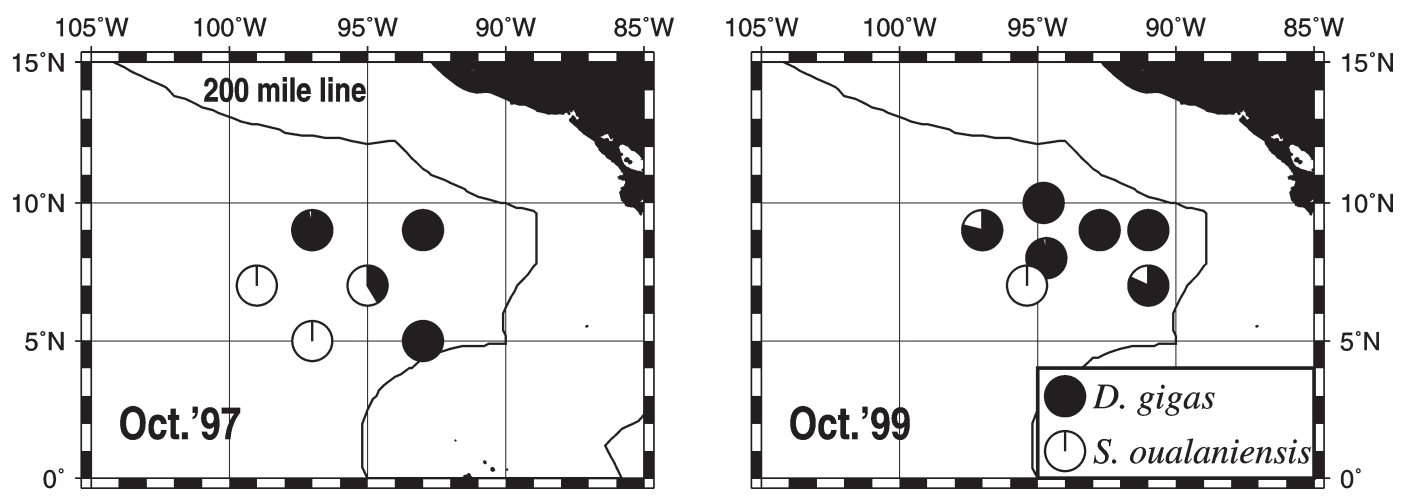

Fig. 10. Catch composition (number) for Dosidicus gigas and Sthenoteuthis oualaniensis caught at research jigging stations, October 1997 and 1999

may be small (Blackburn et al. 1970). Significant positive regressions of chl a standing stocks on both zooplankton and fish-cephalopod micronekton biomass (Blackburn 1966) further suggest that continuously higher chl a concentrations may lead to the formation of a favorable feeding ground for jumbo flying squid.

During La Niña in October 1999, surface chl a concentrations were enhanced in coastal waters, along the equatorial and countercurrent ridges. Integrated chl a concentrations in the upper $100 \mathrm{~m}$ depth, however, were not necessarily higher $\left(\geq 25 \mathrm{mg} \mathrm{m}^{-2}\right)$ all over the countercurrent ridge because higher chl a areas were limited to low surface salinity $(\leq 33.3)$ areas of the ridge. It should be noted that chl a remained low in higher surface salinity areas of the countercurrent ridge in spite of the shallow thermocline (Fig. 9) and subsequent higher nitrate concentrations (data not shown).
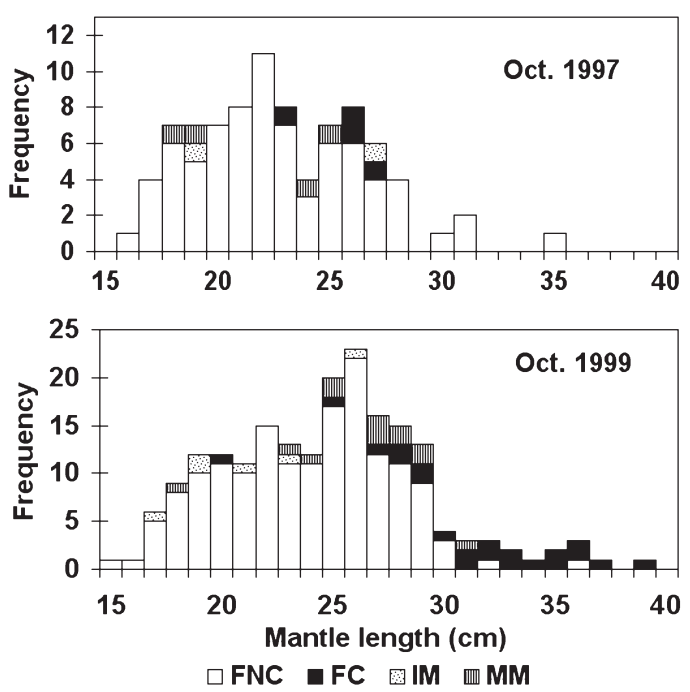

Fig. 11. Mantle length composition of jumbo flying squid obtained with research jigs, October 1997 and 1999. FNC: noncopulated females; FC: copulated females; IM: immature males; MM: mature males (i.e. with complete spermatophores)
In addition to upwelling, a strong salinity front was formed near the surface along the NECC (Fig. 6c). This front may have resulted from the strong 'shear' between the intensified eastward NECC and westward NEC. Wyrtki (1974) showed that the NECC and NEC are strong during El Niño, whereas both currents are weak during La Niña. Ishino (1975) suggested that the oceanic front plays an important role in the formation of fishing grounds through 3 effects, namely the provision of a barrier to fish movement, the accumulation of surface drifting food and the maintenance of high productivity. The strong front evident during this study could have influenced the restriction of jumbo flying squid to the productive ridge area.

Vecchione (1999) attributed the occurrence of a high abundance of ommastrephid paralarvae (probably Dosidicus gigas) in a westward extension of the Costa Rica Dome during the 1987 El Niño, primarily to the warm El Niño waters $\left(29^{\circ} \mathrm{C}\right)$. However, the artificial fertilization experiment indicated no difference in hatching rates between warm El Niño $\left(28^{\circ} \mathrm{C}\right)$ and cooler water temperatures $\left(24^{\circ} \mathrm{C}\right)$. Furthermore, jumbo flying squid are a relatively eurythermic species with an usual preferred temperature range of 15 to $28^{\circ} \mathrm{C}$. The greatest concentrations recorded in the northern hemisphere have been at 25 to $28^{\circ} \mathrm{C}$ (Nesis 1983). Nevárez-Martínez et al. (2000) also indicated that surface temperature does not appear to be a limiting factor for either distribution or abundance. Accordingly, warm El Niño waters are not considered a necessary factor in the formation of a good spawning ground.

During the La Niña period, jumbo flying squid were less abundant along the countercurrent ridge, and there are 2 possible explanations for this. Firstly, changes in their distribution may have occurred, e.g. dispersion over a greater area or movement into more coastal areas (within the 200 n. mile economic zone). NevárezMartínez et al. (2000) indicated that the availability of jumbo flying squid in the Gulf of California (a coastal area) seemed to be negatively impacted by El Niño 

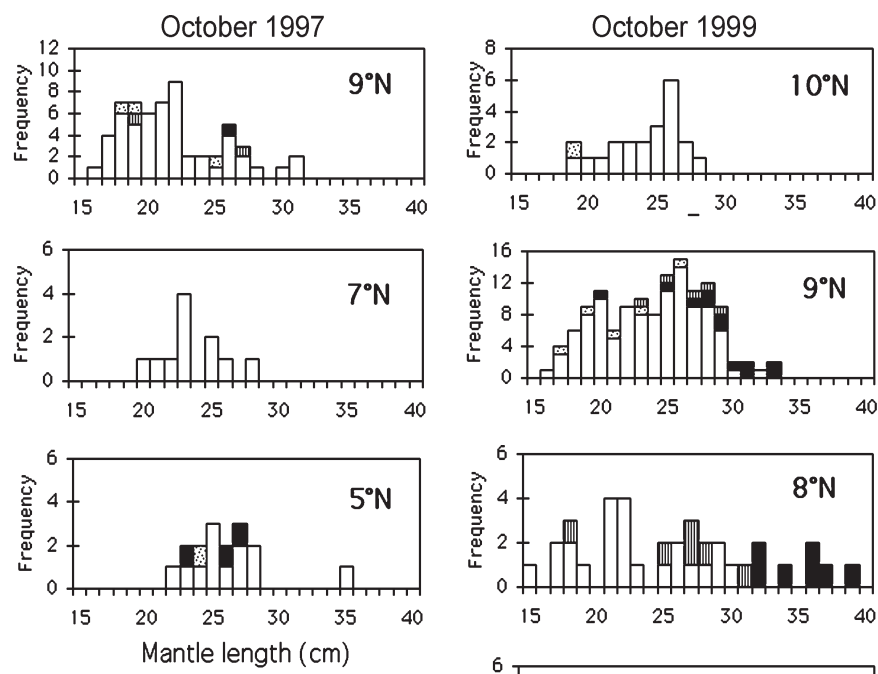

$\square$ FNC $\square$ FC 图 IM 皿 MM

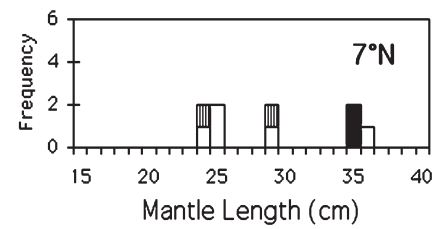

Fig. 12. Mantle length compositions of jumbo flying squid by latitude, October 1997 and 1999. For abbreviations see legend to Fig. 11

events, implying that they tended to increase in number in coastal areas during La Niña and La Niña-prone events, when coastal upwelling tends to be strong. Secondly, as jumbo flying squid are an annual species (Masuda et al. 1998), their abundance is determined by recruitment in the same year as cohorts are hatched. Hence, there may have been poor recruitment for the year class hatched in 1998, but no data are available for clarification of this.

Parish et al. (1981) indicated that the reproductive strategies of many marine species are adapted to the prevailing currents that bring planktonic larvae to their nursery grounds. In both years, mature female jumbo flying squid tended to be more frequently distributed toward the south. Koronkiewicz (1988) also reported that mature females were mainly distributed in the southern area off Costa Rica. A rationale exists for spawning in the south during both El Niño and La Niña conditions: if paralarvae are released in the southern area, where the eastward NECC prevails, they might avoid being transported westwards to the point of no return in the oligotrophic oceanic area.

Mantle length compositions of jumbo flying squid were apparently similar between the years (Fig. 11). To have further information on interannual difference in growth rate, growth analysis should be conducted based on daily increment counts in statolith.
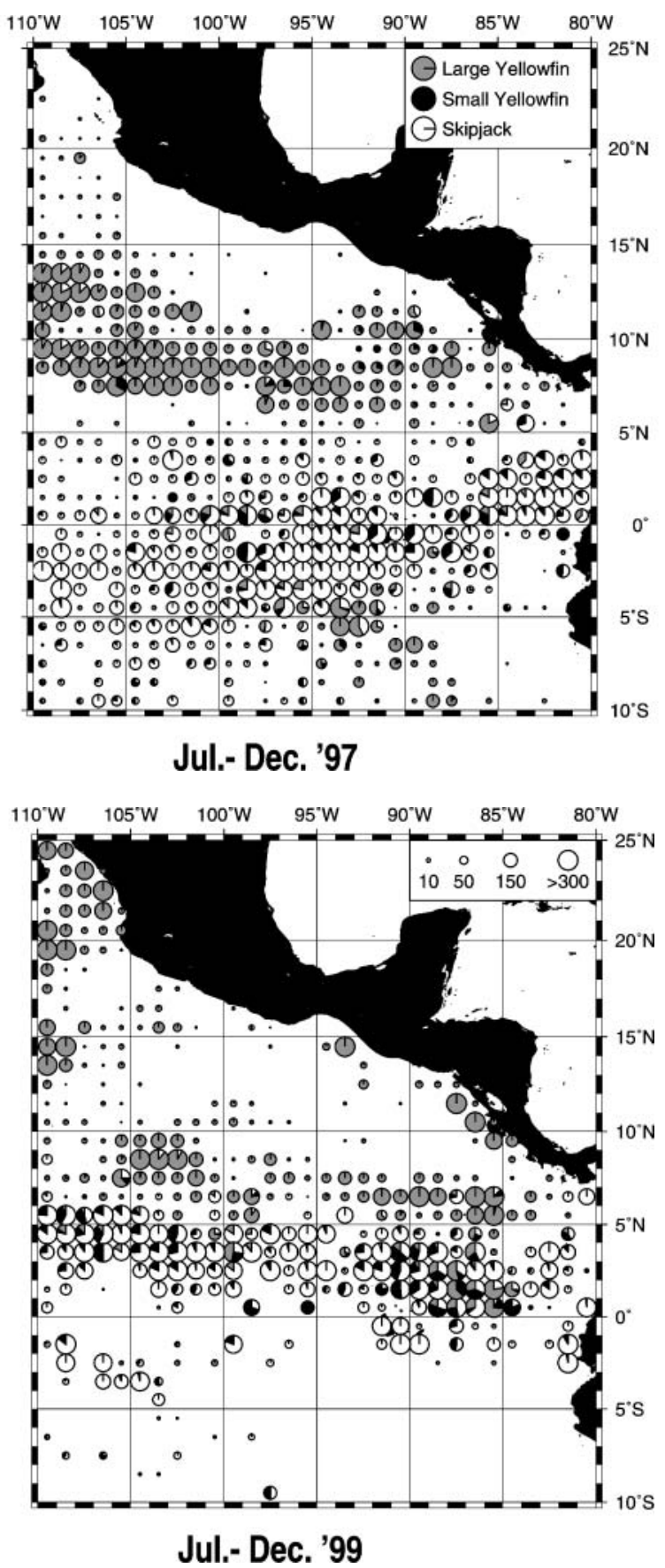

Fig. 13. Catch distribution (tonnes) for large and small yellowfin and for skipjack tuna, July-December 1997 and 1999. Large and small yellowfin are defined as 60 to $140 \mathrm{~cm}$ and 40 to $60 \mathrm{~cm}$ fork length respectively (see Fishery data section in 'Materials and methods')

Prey faunal factors for the association of jumbo flying squid with the countercurrent ridge

Based on exploratory fishery observations made in 1989, 1992 and 1993 (JAMARC 1991, 1994, 1995), 
jumbo flying squid were distributed in equatorial waters, but not in sufficient abundance to support a fishery, indicating that this species is more associated with the countercurrent ridge than the equatorial one. Large yellowfin tuna (60 to $140 \mathrm{~cm}$ fork length) were also associated with the countercurrent ridge, whereas skipjack tuna and small yellowfin tuna $(40$ to $60 \mathrm{~cm})$ were associated with the equatorial ridge.

This poses the question as to why jumbo flying squid and large yellowfin tuna are associated with the countercurrent ridge, and skipjack and small yellowfin tuna with the equatorial ridge? The 2 ridges, both areas of enhanced productivity, are greatly different from each other

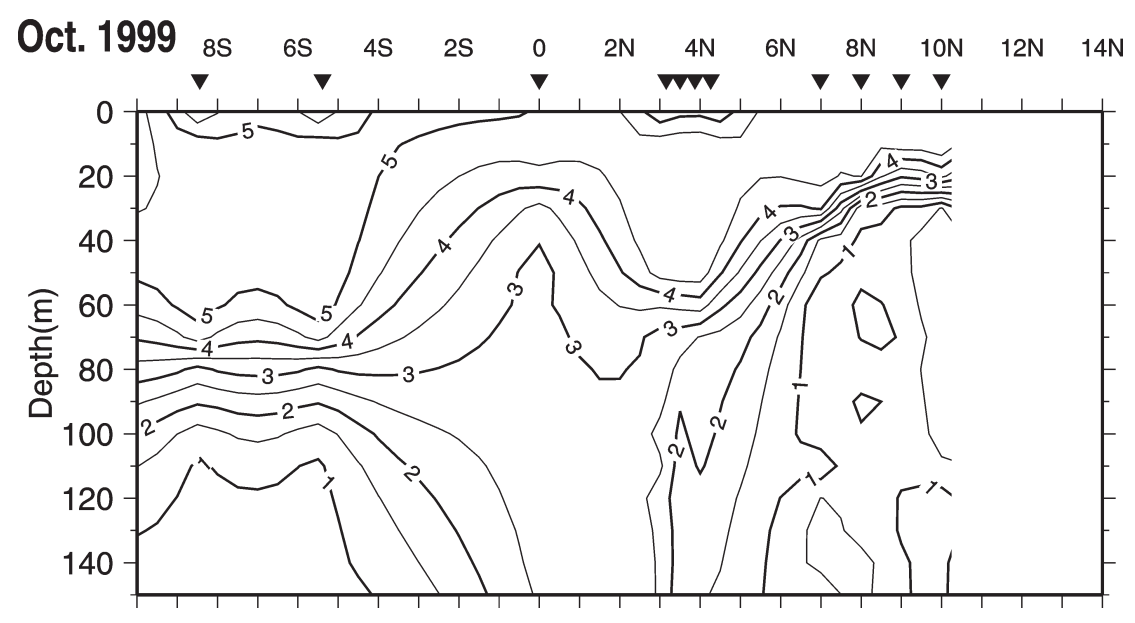
qualitatively (Fig. 7); the countercurrent ridge is characterized by a strong shallow thermocline, the oxygen minimum layer $\left(\leq 1.0 \mathrm{ml} \mathrm{l}^{-1}\right.$; Fig. 14) and warm surface water, whereas the equatorial ridge is characterized by a shallow, weak thermocline, due to the equatorial undercurrent, and cool surface temperature (Au \& Perryman 1985). Skipjack tuna cannot survive in lower dissolved oxygen levels $\left(\leq 1.5 \mathrm{ml} \mathrm{l}^{-1}\right)$ for more than 20 min (Dizon 1977). This oxygen-sensitivity may be partly responsible for their tendency to avoid the countercurrent ridge, associated with the oxygen minimum layer. Furthermore, because their lower temperature limit appears to be ca. $20^{\circ} \mathrm{C}$ (Williams 1970), they may inhabit the warm mass of equatorial surface water during La Niña. Jumbo flying squid and yellowfin tuna, on the other hand, are considered to be more tolerant of oxygen-deficient water (Dizon 1977, Yatsu et al. 1999b), enabling them to utilize the countercurrent ridge.

Prey fauna may also play an important part in the association of jumbo flying squid, yellowfin tuna and skipjack tuna with their respective ridges. The main food items of jumbo flying squid include myctophid fishes, jumbo flying squid (cannibalism), flying fishes and swimming crabs (Portunidae), and those of large yellowfin tuna in the ETP include small scombrid fishes, swimming and red (Galatheidae) crabs, flying fishes and subadult jumbo flying squid (Alverson 1963, Perin et al. 1973, Koronkiewicz 1988). Major food items for skipjack tuna in the ETP include euphausiids, Amphipoda and small bathypelagic fishes (Alverson 1963). Furthermore, small yellowfin tuna occur together with skipjack tuna along the equatorial ridge (Fig. 13), probably responding to a common food source (Yuen 1963), suggesting that yellowfin tuna move from the equatorial ridge to the countercurrent

ridge with growth and a changing diet (increasing percentage of fish) (Alverson 1963). Interestingly, the countercurrent ridge supports fish- and cephalopodfeeding birds rather than plankton-feeding birds that are usually abundant over the equatorial ridge (Love 1971, 1972). Apex predators, such as tunas, seabirds and squid, mainly feeding on micronekton (e.g. small fishes, cephalopods and swimming crabs), may therefore tend to be distributed along the countercurrent ridge, while those mainly feeding on zooplankton (e.g. euphausiids and Amphipoda) occur more along the equatorial ridge. In fact myctophid larvae and small scombrid fishes have been reported as being more abundant along the countercurrent ridge than the equatorial ridge (Love 1971, 1972), suggesting that a more abundant prey fauna for jumbo flying squid along the former ridge is directly related to the association of the latter with that ridge.

\section{Concept of mechanisms causing the variation between El Niño and La Niña conditions}

Fig. 15 shows a schematic diagram illustrating the changing ocean regime and subsequent aggregating/dispersing species in the countercurrent and equatorial ridges. As explained by Wyrtki (1974) and Fiedler (1992), during El Niño, when the northeast trade winds are weak, the NECC intensifies out of phase with the weakened SEC. The strong NECC steepens the countercurrent thermocline slope, while the weaker SEC flattens the equatorial thermocline slope. The eastward transport of warm waters by the strong NECC causes an accumulation of huge masses of warm surface water and subsequent thermocline 

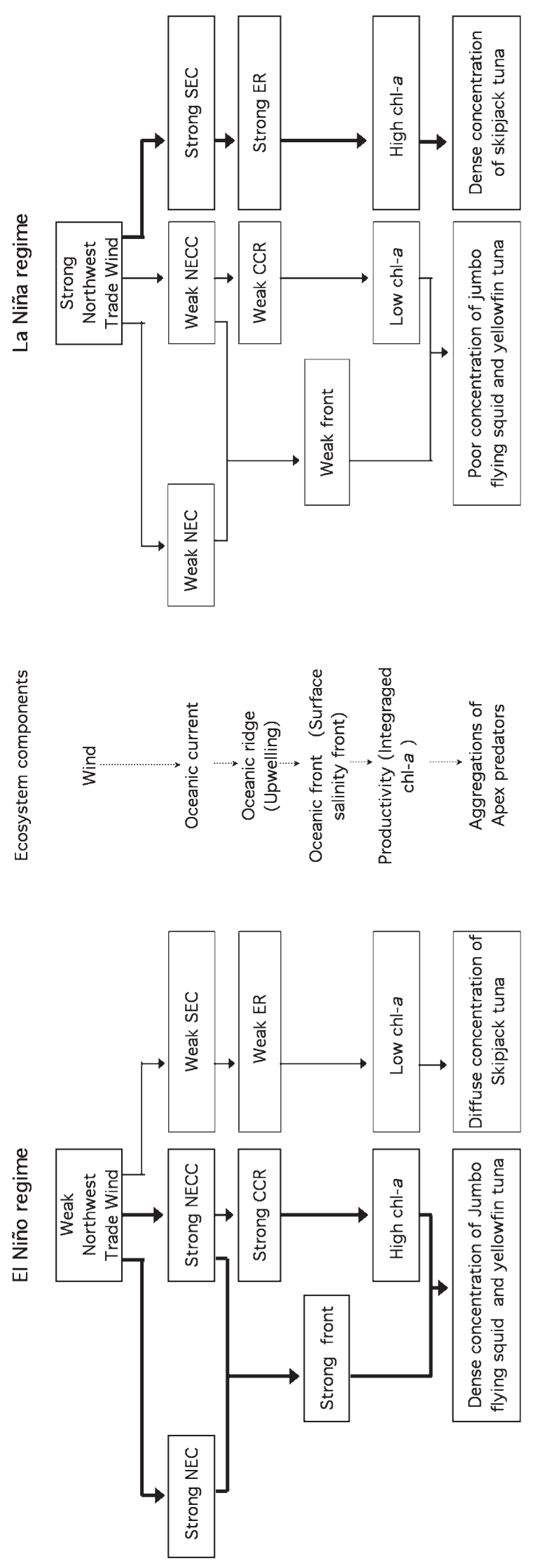

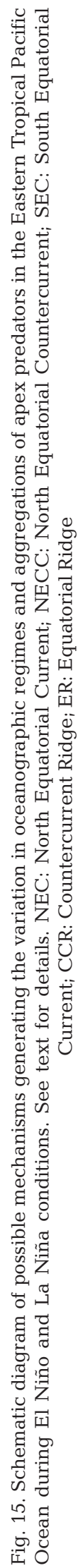

depression at the equator. During La Niña, when the northeast trade winds are strong, the NECC is weak, flattening the countercurrent thermocline slope, whereas the stronger SEC steepens the equatorial thermocline slope.

Two features of the well-developed countercurrent ridge are considered important for the occurrence of high jumbo flying squid concentrations during an El Niño event. Firstly, relatively higher integrated chl a concentrations along the countercurrent ridge may lead to the formation of a favorable feeding ground for jumbo flying squid. Secondly, a strong salinity front formed between the NECC and NEC is possibly responsible for retention of jumbo flying squid in the ridge.

El Niño/La Niña events influence tuna distributions in a manner similar to that of jumbo flying squid. Large yellowfin tuna are more concentrated along the countercurrent ridge during El Niño, when that ridge is well-developed. Similarly, skipjack tuna and small yellowfin tuna tend to be more concentrated along the equatorial ridge during La Niña, when the ridge is well developed (Fig. 15).

Acknowledgements. We thank the IATTC, particularly G. Watters and M. Hinton, for providing tuna catch data from purse seiners. Our thanks are also due to Prof. Y. Sakurai for supplying oviducal gland power for artificial fertilization of jumbo flying squid. N. Cho kindly helped the artificial fertilization experiment. We are also grateful to M. Okazaki, N. Kimura, G. Sakagawa, K. Uehara, N. Miyabe, T. Nishida, S. Hashimoto, T. Tanabe and M. Ogura for their useful comments. Our sincere thanks are due to the captains, officers and crew of the RV 'Shoyo Maru' and the RV 'Kaiyo Maru' for their assistance during the cruises. We also thank the SeaWiFS Project and the Distributed Active Archive Center at the NASA Goddard Space Flight Center for the SeaWiFS data, and the Jet Propulsion Laboratory (NASA) for SST data.

\section{LITERATURE CITED}

Alverson FG (1963) The food of yellowfin and skipjack tunas in the eastern tropical Pacific Ocean. Inter-Am Trop Tuna Comm Bull 7:293-396

Au DWK, Perryman WL (1985) Dolphin habitats in the eastern tropical Pacific. Fish Bull 83:623-643

Blackburn M (1966) Relationships between standing crops at three successive trophic levels in the eastern trophic Pacific. Pacific Sci 20:36-59

Blackburn M, Laurs RM, Owen RW, Zeitzschel B (1970) Seasonal and areal changes in standing stocks of phytoplankton, zooplankton and micronekton in the eastern tropical Pacific. Mar Biol 7:14-31

Brandhorst W (1985) Thermocline topography, zooplankton standing crop and mechanisms of fertilization in the eastern tropical Pacific. J Cons Int Explor Mer 24:16-31

Campbell JW, Baisdell JM, Darzi M (1995) Level-3 SeaWiFS Data Products: spatial and temporal binning algorithms. In: Hooker SB, Firestone ER (eds) NASA technical memorandum 104566, Vol 32. NASA Goddard Space Flight Center, Greenbelt, MD 
Dizon AE (1977) Effect of dissolved oxygen concentration and salinity on swimming speed of two species of tunas. Fish Bull 75:649-653

Donguy JR, Meyers G (1987) Observed and modelled topography of the $20^{\circ} \mathrm{C}$ isotherm in the tropical Pacific. Oceanol Acta 10:41-48

Fiedler PC (1992) Seasonal climatologies and variability of eastern tropical Pacific surface waters. NOAA Tech Rep NMFS 109

Fiedler PC, Philbrick V (1991) Oceanic upwelling and productivity in the eastern tropical Pacific. Limnol Oceanogr 36:1834-1850

Fiedler PC, Chavez FP, Behringer DW, Reilly SB (1992) Physical and biological effects of Los Niños in the eastern tropical Pacific, 1986-1989. Deep-Sea Res 39:199-219

IATTC (1989) Annual report, 1988. Inter-American Tropical Tuna Commission, La Jolla, CA

IATTC (1999) Annual report, 1997. Inter-American Tropical Tuna Commission, La Jolla, CA

Ishino $M$ (1975) Basic idea on fishing ground environments. In: Hirano B (ed) Marine living resources environments. Tokyo University Press, p 87-99 (in Japanese)

JAMARC (1991) Report on development of new fishing grounds for squid jigging in 1989. Japan Marine Fishery Resource Center, Tokyo (in Japanese)

JAMARC (1994) Report on development of new fishing grounds for squid jigging in 1992. Japan Marine Fishery Resource Center (in Japanese)

JAMARC (1995) Report on development of new fishing grounds for squid jigging in 1993. Japan Marine Fishery Resource Center, Tokyo (in Japanese)

Koronkiewicz A (1988) Biological characteristics of jumbo squid (Dosidicus gigas) caught in open waters of the eastern central Pacific from October to December 1986. ICES CM 1988/K:42

Levitus S, Boyer TP (1994) World Ocean Atlas 1994, Vol 4: temperature. NOAA Atlas NESDIS 4, US Department of Commerce, Washington, DC

Love CM (1971) Biological and nutrient chemistry data from principal participating ships, first survey cruise, February-March 1967. EASTROPAC Atlas 2, Natl Mar Fish Serv Circ 330, p 1-80

Love CM (1972) Biological and nutrient chemistry data from principal participating ships, second survey cruise, AugustMarch 1967. EASTROPAC Atlas 6, Natl Mar Fish Serv Circ 330, p 1-87

Mann KH, Lazier JRN (1991) Dynamics of marine ecosystems: biological-physical interactions in the oceans. Blackwell Scientific Publications, Oxford

Masuda S, Yokawa K, Yatsu A, Kawahara S (1998) Growth and population structure of Dosidicus gigas in the southeastern Pacific Ocean. In: Okutani T (ed) Large pelagic squids. Japan Marine Fishery Resources Research Center, Tokyo, p 107-118

McClain CR (2000) SeaWiFS postlaunch calibration and validation overview. In: McClain CR, Ainsworth EJ, Barnes RA, Eplee RE Jr, Patt FS, Robinson WD, Wang M, Bailey SW (eds) SeaWiFS postlaunch calibration and validation analyses, Part 1, Hooker SB, Firestone ER (Series eds) NASA Tech Mem 206892, Vol 9, NASA Goddard Space Flight Center, Greenbelt, MD, p 4-12

McPhaden MJ (1999) Genesis and evolution of the 1997-98 El Nino. Science 283:950-954

Editorial responsibility: Otto Kinne (Editor), Oldendorf/Luhe, Germany
Nesis KN (1983) Dosidicus gigas. In: Boyle PR (ed) Cephalopod life cycles, Vol 1. Academic Press, London, p 215-231

Nevárez-Martínez MO, Hernández-Herrera A, Morales-Bojórquez E, Balmori-Ramírez A, Cisneros-Mata MA, MoralesAzpeitia R (2000) Biomass and distribution of the jumbo squid (Dosidicus gigas; d'Orbigny, 1983) in the Gulf of California, Mexico. Fish Res 1072:1-12

Parish RH, Nelson CS, Bakun A (1981) Transport mechanisms and reproductive success of fishes in the California Current. Biol Oceanogr 1:175-203

Parsons TR, Maita Y, Lalli CM (1984a) A manual of chemical and biological methods for seawater analysis. Pergamon Press, Oxford

Parsons TR, Takahashi M, Hargrave B (1984b) Biological oceanographic processes, 3rd edn. Pergamon Press, Oxford

Perrin WF, Warner RR, Fiscus CH, Holts DB (1973) Stomach contents of porpoise, Stenella spp., and yellowfin tuna, Thunnus albacares, in mixed-species aggregations. Fish Bull 71:1077-1092

Sakurai Y, Young RE, Hirota J, Mangold K, Vecchione M, Clarke MR, Bower J (1995) Artificial fertilization and development through hatching in the oceanic squids Ommastrephes bartramii and Sthenoteuthis oualaniensis (Cephalopoda: Ommastrephidae). Veliger 38(3):185-191

Shiomoto A (1999) Chlorophyll a concentration and standing stock by station. Report of the Kaiyo Maru Cruise for study on the resources of two ommastrephid squids, Dosidicus gigas and Ommastrephes bartrami, in the Pacific Ocean, during September 11-December 24, 1997. Fishery Agency of Japan, Tokyo, p 59

Sverdrup HU, Johnson MW, Fleming RH (1942) The oceans: their physics, chemistry and general biology, PrenticeHall, Englewood Cliffs, NJ

Vazquez J, Perry K, Kilpatrick K (1998) NOAA/NASA AVHRR oceans pathfinder sea surface temperature data set user's reference manual, v.4.0. JPL Publication D-14070, NASA Jet Propulsion Laboratory, Pasadena, CA (available at http://podaac.jpl.nasa.gov/sst/)

Vecchione M (1999) Extraordinary abundance of squid paralarvae in the tropical eastern Pacific Ocean during El Niño of 1987. Fish Bull 97:1025-1030

Williams F (1970) Sea surface temperature and the distribution and apparent abundance of skipjack (Katsuwonus pelamis) in the eastern Pacific Ocean 1951-1968. InterAm Trop Tuna Comm Bull 15:229-281

Wyrtki K (1966) Oceanography of the eastern equatorial Pacific Ocean. Oceanogr Mar Biol Ann Rev 4:33-68

Wyrtki K (1974) Equatorial currents in the Pacific 1950 to 1970 and their relations to the trade winds. J Phys Oceanogr 4:372-380

Yatsu A, Tafur R, Maravi C (1999a) Embryos and rhynchoteuthion paralarvae of the jumbo flying squid Dosidicus gigas (Cephalopoda) obtained through artificial fertilization from Peruvian waters. Fish Sci 65:904-908

Yatsu A, Yamanaka K, Yamashiro C (1999b) Tracking experiments of the jumbo flying squid, Dosidicus gigas, with an ultrasonic telemetry system in the eastern Pacific Ocean. Bull Nat Inst Far Seas Fish 36:55-60

Yuen HSH (1963) Schooling behavior within aggregations composed of yellowfin and skipjack tuna. FAO Fish Rep 6: $1419-1429$

Submitted: April 11, 2001; Accepted: July 10, 2001

Proofs received from author(s): March 19, 2002 